\title{
運動時循環の交感神経性調節
}

斉藤 満

\section{Sympathetic neural control of the circulation during exercise}

\author{
Mitsuru Saito
}

\begin{abstract}
Sympathetic neural control of the cardiovascular system plays a crucial role in supplying oxygen from the lung to the contracting skeletal muscle during exercise to meet the increased metabolic rate. Direct recording of human sympathetic nerve activity, i.e. microneurography, has provided a wealth of new findings, as follows: 1 . The muscle metabo- and mechano-reflex is essential to the normal rise in muscle sympathetic nerve activity (MSNA) during static and rhythmic handgrip exercise. 2. Exercise intensity and duration influence the extent of MSNA during dynamic cycling exercise. MSNA increases in proportion to exercise intensity, which is governed by peripheral reflex and central control mechanisms. At maximal exercise, the strong MSNA response seems to be caused mainly by increased central command. 3. During prolonged low-intensity cycling, MSNA increases in association with a fall in blood pressure. Thus, the baroreflex may play a key role of the increase of MSNA. The present review addresses what mechanism is important for control of the sympathetic nervous system during exercise based on the actual MSNA response during different forms of exercise. The results suggest that MSNA during dynamic exercise is controlled by many inputs from the central and peripheral areas, whereas there has been little study of the MSNA response to dynamic exercise. It will be necessary to accumulate further studies to confirm precise details of neural control of the circulation during dynamic exercise.
\end{abstract}

Key words : muscle reflex, baroreflex, central command, dynamic exercise, static exercise

(Japan J. Phys. Educ. Hith. Sport Sci. 47: 491-497, September, 2002)

キーワード：活動筋反射，圧受容器反射，セント

ラルコマンド, ダイナミック運動,

Iはじめに

スタティック運動

単細胞からなる原始的な生物は細胞膜をとおし

豊田工業大学応用生理研究室

T 468-8511 名古屋市天白区久方 2-12

連絡先 斉藤 渵
Applied Physiology Laboratory, Toyota Technological Institute

2-12 Hisakata, Tempaku-ku, Nagoya 468-8511

Correspondingauthor msaito@toyota-tiac.jp 
て直接酸素や栄養を取り入れ生活を営むが，ヒト のように多くの細胞からなる生物の細胞は，外界 から直接酸素や栄養を取り入れることができず， 酸素を必要とする細胞と酸素を取り入れる肺との 間をつなぐ心臓と血管からなる循環系の助けを借 りることになる。この場合, 酸素を必要とする部 位からの情報の受容と循環調節が不可欠となる. この調節には感覚系, 内分泌系そして自律神経系 が協同してあたり，なかでも自律神経系の役割が 直接的で最も大きく, 循環調節研究の中心となる.

細胞の代謝は安静から運動に移ると急激に高ま り, 酸素の消費が一気に増加する．さらに運動が 激しくなると大量の酸素を必要としこれに応える 調節が必要である．この調節が適切に行われるか どうかは, 運動がすみやかに遂行できるかどうか, パフォーマンスが高められるかどうかを決定する 重要なファクターになり，その巧みなしくみは 100 年以上前から興味がもたれ今日なおその追求 が続いている。

\section{II 研究の流れ}

運動時の素早い血液供給の上昇には皮質からの 入力が重要であるという考えは，Johansson （1895）がウサギを用いて皮質を刺激し心拍数が 増加することを報告したことに始まる，いわゆる セントラルコマンド (central command）の基礎 となる考えである．また，運動時の昇圧反応に関 しては, Alam and Smirk（1937）は，掌握運動 後の活動筋血流を遮断するという実にアイデアに 富んだ実験系を用い，活動筋からの反射（末梢調 節）が昇圧原因の一つであることを証明した。こ れらの研究は心拍数 (拍出量) を増加し活動筋に 素早く血流を供給するための中枢性調節および末 梢反射調節の基本的な考えを提出したものであ る.それ以来両者の調節に関わる詳細な仕組みの 解明が続いている (Mitchell, 1990).

初期の研究は, 先の例で示したように心拍や血 圧, あるいは末梢血流 (血管) などの効果器反応 による研究が中心であったが, 神経生理や薬理学 の進展, さらに研究手法の開発にともない, 効果
器反応の観察だけでなく，これを支配する交感神 経終末から分泌されるノルエピネプェリン $(\mathrm{NE})$, カテコールアミン (CA）の解析，さらに神経遮 断剂を用いた研究が導入された。1980年代から はこれらに加え，ヒトの交感神経活動の直接記録 法（Microneurography）が応用されはじめ，最 近では遺伝子解析法を用いた研究が広がりつつあ る.ここでは Microneurographyを用いた最近の 運動時循環の神経調節研究について述べる。

\section{Microneurographyによる 交感神経活動観察}

Microneurographyは金属微小電極を末梢神経 に直接刺入して交感神経活動を観察する手法で, 1960 年代後半 Hagbarth and Vallbo（1968）によ って開発された．初期は主に運動や感覚神経研究 に用いられ，交感神経研究への応用は比較的少な かった．特に運動時循環の神経調節研究に本格的 に応用されはじめたのは Mark et al.（1985）が 1985 年に報告した論文以降といえる（斉藤， 1997）。彼等は最大随意収縮（MVC）の $30 \% の$ 静的掌握運動を 2 分行い，運動停止直前に活動筋 動静脈血を停止し，その際の骨格筋支配の交感神 経活動を観察した。この結果, 運動停止後も活発 な交感神経活動が持続すると同時に高血圧が維持 されることを示し，活動筋からの反射により交感 神経活動が高められるという，Alam and Smirk （1937）の仮説を直接的に示した。

本方法の特徴はこれまでの血管反応や薬理学的 な方法に比べて時間分解能が高く，しかも実時間 で観察できることである（斉藤，2001）。血管な どの効果器反応には神経調節が反映されるが，こ こには調節信号以外の調節因子も入り込むため正 確に信号を取りだせないことがある：また，交感 神経活動を反映する血中 CA N NEは，漏出まで の遅延があり，一部は組織で再吸収されるという 短所がある。ただ，前者では一部の限局された神 経活動しか観察できないという短所を持つが，後 者は全身の交感神経活動の総和としてみることが できる長所をもつ。

Microneurographyの長所を生かして最初に確 
かめられた大きな成果は（Mark et al., 1985）, (1)交感神経活動は運動開始から遅れて高まり，す ぐには高まらないこと, (2)運動停止や動脈阻血解 除後交感神経活動はすみやかに安静值に回復する こと，である。これらの結果は循環調節における 活動筋代謝受容器反射の重要性を示唆し, 代謝受 容器反射のメカニズム研究を活発化させる大きな きっかけとなった。

\section{IV 運動の種類と交感神経反応}

運動時の循環反応は運動の種類や時間, 方法で 大きく異なる．たとえば，静的運動では心拍出量 の増加は小さいが昇圧反応が大きい, 動的運動で は拍出量が大きく増加するにもかかわらず昇圧反 応は小さいといった差異がみられる。このような 違いの背景には神経調節の違いがあることは疑う 余地はない。これまでの MSNA 観察による運動 時循環の神経調節研究はおもに掌握運動モデルを 中心にして進められ，掌握運動以外の上肢や下肢 の運動による研究は比較的少ない。また，運動時 間も比較的短かく，特に下肢を用いた大筋群のダ イナミックな運動は数える程しか報告されていな w.

静的掌握運動時の MSNA 增加には間值がある とされ，その闇值は最大握力の $10-20 \%$ 張力で (Seals et al., 1988), 閾值を超える運動強度でも 運動開始から遅れて活動が高まり，静的最大掌握 運動でも運動開始に遅れる（Hashimoto et al., 1997)。下肢では静的下腿伸展，足底屈，足背屈 運動などが用いられている（Ray and Mark 1993， Saito, 1995)。これらの運動でも静的掌握運動と ほほ同様の反応が観察されるが，運動強度に対す る亢進の䦭值は筋群によって異り，足底屈運動よ り足背屈運動の MSNA元進閥值が低くなる (Saito，1995)。また，30\% MVCの静的下腿伸 展運動ではMSNA 増加に 1 分以上要し, 同程度 強度の掌握運動に比べて MSNA六進が遅れる (Ray and Mark 1993).

間欠的な等尺性筋収縮運動 (Victor et al., 1987）においてもほぼ静的運動と同樣の反応を示
すが，掌握張力の閾值は静的運動より高い。この ようなMSNA 反応の特徵には代謝受容器反射が 関係する（Victor et al.，1988）。すなわち MSNA 上昇に閾值があるのは代謝受容器を刺激するため に必要な代謝産物の蓄積があるかどうかによるも ので, 運動開始から MSNA 増加が遅れるのは代 謝産物の蓄積に時間を要するためと考えられる (Hashimoto et al., 1997, Victor et al., 1988).

短縮性筋収縮の律動的掌握運動を用いた運動時 の反応もほほ静的掌握運動に類似した反応が観察 される。しかし，MSNAの六進間値は掌握張力 で比較すると律動運動で高くなる (Saito et al., 1989）。またこの閥值は収縮頻度によって大き く変化し, 同じ張力でも高い頻度で高くなる. 他 方, 律動的掌握運動（等尺性または短縮性収縮） では運動時間が長くなると代謝産物である乳酸が 活動筋組織に増加しなくても MSNA が高まるこ とが報告されている（Batman et al., 1984）。こ の場合の MSNA亢進原因の一つに活動筋機械受 容器反射が考えられている（Batman et al., 1984, Herr et al., 1999).

\section{V ダイナミック運動時のMSNA}

交感神経活動を反映する血中 CA 濃度変化は片 脚下腿伸展運動, 自転車運動（片脚, 雨脚）で観 察されているが, この反応は代謝量（運動強度） と密接な関係があり，同時に活動笳量にも影響さ れる (Savard et al., 1989). Saito and Mano （1991）は片脚自転車運動時の MSNAを観察し, 代謝量（酸素摄取量）の増加にともない高まるこ とを認めた。しかし, 静的片脚下腿伸展運動時の MSNA と比較すると自転車運動の酸素攝取量が 高いにもかかわらずMSNAが低くなり，酸素搨 取量とMSNAとの間には直接的な関係はない。 このことは，タイナミック運動の MSNA 反応は 小筋群の運動や静的運動と異なることを示し, 運 動時循環の神経性調節が異なることを示唆する.

運動強度：腕エルゴメータ運動あるいは自転車 運動ではMSNAは運動強度に比例して高まる (Saito et al., 1993, Victor et al., 1987). しかし, 
両者の MSNA 増加の閾値は腕エルゴメータ運動 では最大運動の $33 \%$ （Victor et al., 1987），自転 車運動では36\%（Saito et al., 1993）と報告され ている。また, 低い運動強度の自転車運動や下腿 伸展運動では, MSNA は運動前安静値より低下 することが観察され（Ray 1993a，1993b，Saito et al., 1993)，運動時には交感神経活動が高まる と言う従来からの常識と異なる結果が報告されて いる.このような結果は，交感神経活動が本当に ダイナミック運動時に抑制されるのか，運動時の MSNA 増加にはきまった閾値があるのかといっ た問題を提起する.

Rowell et al.（1996）は運動強度と交感神経活 動の関係についてこれまでの研究をまとめ, 交感 神経活動増加の閾値は心拍数が毎分 100 拍のとこ ろにあると述べているが, Saito et al.（1993）は 軽強度運動では一旦交感神経活動は抑制され，そ の後高まると考えた（図1）。この考えに対し， Rowell et al.（1996）は運動時の MSNA 低下は運 動前安静値より抑制されたと考えるより，運動時 の最初のレベルを基準值としてみるべきであろう と主張している（図1）。こうすれば，交感神経 活動艺進閥值は運動時の心拍数が 100 拍/分で一 致するという．再者の考え方の違いは単に運動時 に交感神経活動が抑制されるとか充進に閾值があ るのかと言う問題に止まらず，交感神経活動調節 の基準値とは何かといった基本的な課題を提出す る.

もし，運動時の交感神経活動が活動筋反射のみ できまるとすれば，Rowell et al.（1996）の考え も成り立つであろう。しかし，運動時のMSNA は活動筋からの反射だけでなく，七ントラルコマ ンド (Victor et al., 1995), 動静脈圧受容器（斉 藤，2001）, さらに呼吸運動（Eckberg et al., 1985）や末梢化学受容器（Saito et al., 1991）か らの入力を受容し，これらが統合されてMSNA 出力がきまる。したがって，これらがどこでどの ように統合されるか明らかにすることは神経調節 の今後の重要な課題である。特に活動筋からの反 射（MSNA 促進）と全身循環を監視する圧受容 器（MSNA 抑制）からの入力がそれぞれどのよ

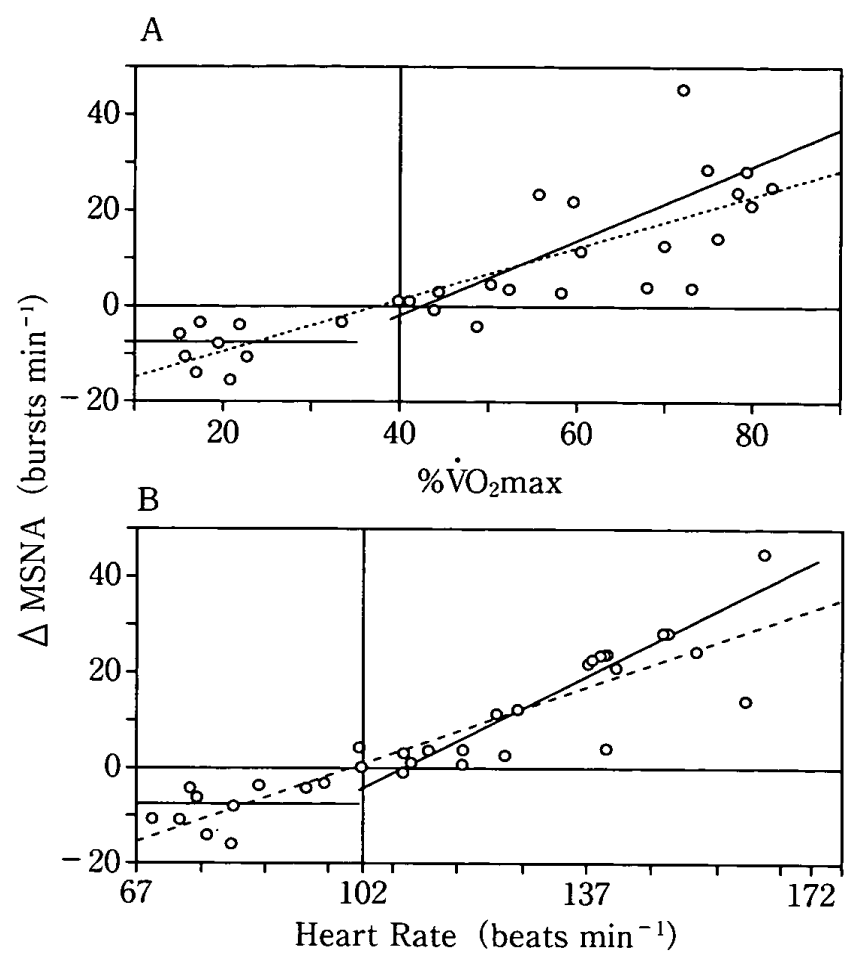

図 1 運動強度と筋交感神経活動の関係 (Rowell et al., 1996, Saito et al., 1993).

上段 $\mathrm{A}$ は酸素搷取量と筋交感神経活動の関係，下段 B は心拍数と筋交感神経活動の関係.

運動強度と筋交感神経反応の関係を Saitoたちは，筋交 感神経活動は低強度運動で安静より抑制され，その後運 動強度に比例して連続的に高まるとした (点線)。これ に対し，Rowellたちは運動前の安静筋交感神経活動に は姿勢の影響が含まれるため，運動時の筋交感神経活動 低下を抑制とは考えず，運動時の最低レベルを交感神経 活動基準值とし，交感神経活動を 2 本の実線で表すのが 妥当とした。これにより交感神経活動增加の䦭値は心拍 数でおよそ 100 拍/分，酸素摄取量でおよそ $40 \%$ $\dot{\mathrm{V}} \mathrm{O}_{2} \max に$ 相当するとしている.

MSNA, 筋交感神経活動, $\dot{\mathrm{V}} \mathrm{O}_{2} \mathrm{max}$, 最大酸素掑取量.

うな相互作用を営んでいるのか明らかにすること は当面の重要課題である.

運動時間：長時間運動の心循環反応をみると一 定強度の運動であっても心拍数が徐々に上昇し, 血圧は低下する（Ekelund，1967）。この理由に ついては明らかとなっていないが，この時の交感 神経活動は低下しているのか，あるいは高まって いるのかは興味ある点である. Saito et al.（1997） は血中乳酸濃度が上昇しないような低強度の長時 間自転車運動では，MSNA は運動初期に抑制さ れ，運動時間が延長するにと徐々に高まることを 報告した。したがって，長時間運動では交感神経 
活動は高まるにもかかわらず心拍数が渐増し血圧 が低下することが明らかとなった。この程度の低 強度運動では活動筋代謝受容器刺激はほとんど考 えられないので，MSNA六進の原因としてはこ れ以外の因子を考えなければならない。たとえば 活動筋機械受容器からの反射 (Herr et al., 1999), さらに筋疲労に伴うセントラルコマンドの増加な ど（Saito et al.，1989）が考えられ，特に体温上 昇とそれに伴う血圧低下が重要と考えられる (Saito et al., 1997).これに対し，Ray（1993b） は 45 分間の 30 ワット片脚下腿伸展運動において MSNA は初期に抑制され，運動の後半では運動 前安静値まで増加したがそれ以上増えなかったと 報告している．両者の違いには活動筋量や運動強 度の差異が関係すると考えられるが，さらに検討 が必要である。

最大運動：最大運動は心循環系が限界で機能 し，この時の調節に交感神経活動がどのように関 与するかは極めて興味深い。これまでに報告され ているCAの反応結果によれば運動強度が中程度 から最大まで指数関数的に急激に上昇する (Håggendal et al., 1970). 最大運動時の MSNA 記録は技術的な点で極めて難しいが，一例報告さ れている（Saito et al.，1999）。これによれば疲 労困䣏に達し運動が続けられなくなる数十秒前に なってはじめて MSNA 活動が最大值（毎心拍毎 にバースト発射がみられる）に達することが観察 される（図2）。疲労困花時の高いMSNA 活動が どうして生じたかについて考察するに足る充分な 資料は得られていないが，著者たちは運動停止直 前の運動強度は一定であることから活動筋の代謝 や筋機械受容器刺激が急激に增えたとは考えられ ないので，筋疲労に伴うセントラルコマンドの增 大が最も大きいと考えている。これ以外には，高 い換気量を達成するための呼吸筋からの反射，さ らに運動にともなう末梢血管拡張が心拍出量を超 え血圧が低下して圧受容器からの抑制入力が減少 した可能性がある（Pawelczyk et al., 1992）.

交感神経活動が運動で高まることは明らかとな ったが，この立進が単にセントラルコマンドと活 動筋反射だけでは説明できないことが長時間運動
Rest $\mathrm{HR}=78 \mathrm{BF}=42$

ECG

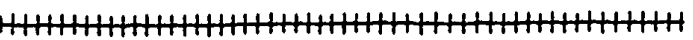

EMG

MSNA

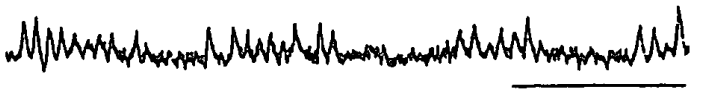

$10 \mathrm{sec}$

$23 \%$ of $\dot{\mathrm{W}}_{\text {peak }}(60 \mathrm{Watt}) \mathrm{HR}=98 \mathrm{BF}=46$

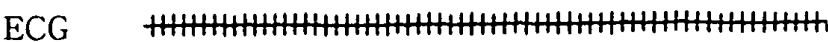

EMG

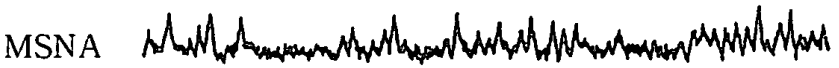

$62 \%$ of $\dot{\mathrm{W}}_{\text {peak }}(160 \mathrm{Watt}) \mathrm{HR}=150 \mathrm{BF}=48$

ECG

EMG

MSNA

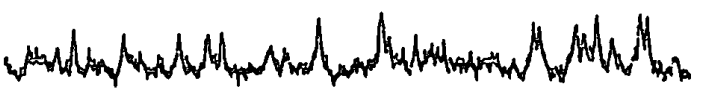

$85 \%$ of $\dot{\mathrm{W}}_{\text {pcak }}(220 \mathrm{Watt}) \mathrm{HR}=182 \mathrm{BF}=98$

ECG

EMG

MSNA

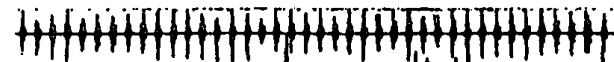
Whuth $\overline{\mathrm{A}} \overline{\mathrm{B}}$ C $Q \operatorname{Rec}$

図2 最大運動時の筋交感神経活動（Saito et al., 1999). 筋交感神経活動のバースト発射頻度は運動強度の增加に ともない增加する. 最大連動では運動停止数十秒前から 心拍に同期してバースト発射がほほ毎回みられる（線 C). 疲労困倠に達し，運動を停止すると同時にバース 卜発射頻度は低下する。

ECG，心電図，EMG，大腿表面筋電図，MSNA，筋交 感神経活動, BP, 血压, $\mathrm{HR}$, 心拍数 (拍/分), $\mathrm{BF}$, 筋交感神経活動バースト発射频度 (バースト/分)， $\mathrm{Q}$, 運動停止, Rec, 回復.

や最大運動の MSNA 反応から明らかとなった。 すなわち，神経調節は活動筋への血流（酸素）の 供給に止まらず循環系ホメオスタシス（homeostasis）（血圧維持）に重要な役割をしていると 考えられる.したがって，圧受容器からの入力が 運動時の交感神経出力に大きな影響を及ほしてい ると考えられ，活動筋反射やセントラルコマンド と合わせて交感神経活動への影響を正確に定量す ることが求められる.

他方，なぜ骨格筋血管を収縮するMSNA が運 動時に高まるのか. MSNAの生理的役割として 
は活動筋に血流を再分配する意義を持つとされる が（Joyner，1991），本当に活動筋血流を低下さ せないのか (Hansen et al., 1996, Joyner et al., 1992)，この点についても妥当な解答が望まれて いる.

\section{VI 要 約}

様々の運動におけるMSNA 反応の例から運動 時循環の神経調節について概観した。運動時の交 感神経え進や抑制メカニズムの研究には掌握運動 が広く用いられ，交感神経活動増加に活動筋代謝 および機械受容器反射が大きく貢献していること が明らかになった。また，ダイナミック運動では, 高い交感神経活動維持に压受容器反射の寄与の大 きい可能性が, 疲労困䣏に到る最大運動ではセン トラルコマンドが大きく関与する可能性が示唆さ れている．運動の種類や強度，運動時間に応じて 神経調節がどう最適に行われるか詳紐を明らかに するためには，さらにダイナミック運動時のデー 夕の蓄積が望まれる。

\section{謝辞}

本内容は科学研究費補助金（課題番号 13680064）による研究の一部としてまとめた。

\section{文献}

Alam, M. and Smirk, F.H. (1937) Observations in man upon a blood pressure rising reflex arising from the voluntary muscles. J. Physiol. Lond. 89: 372383.

Batman, B.A., Hardy, J.C., Leuenberger, U.A., Smith, M.B., Yang, Q.X., and Sinoway, L.I. (1984) Sympathetic nerve activity during prolonged rhythmic forearm exercise. J. Appl. Physiol. 76: 1077-1081.

Eckberg, D.L., Nerhed, C., and Wallin, G.B. (1985) Respiratory modulation of muscle sympathetic and vagal cardiac outflow in man. J. Physiol. Lond. 365: 181-196.

Ekelund, L.-G. (1967) Circulatory and respiratory adaptation during prolonged exercise of moderate intensity in the sitting position. Acta Physiol.
Scand. $69: 327-340$.

Hagbarth, K.-H. and Valbo, Å. B. (1968) Pluse and respiratory grouping of sympathetic impulses in human muscle nerve. Acta Physiol. Scand. 74: 96108.

Håggendal, J., Hartley, L., and Saltin, B. (1970) Arterial noradrenaline concentration during exercise in relation to the relative work levels. Scand. J. Clin. Lab. Invest. 26: 337-342.

Hansen, J., Thomas, G.D., Harris, S.A., Parsons, W.J., and Victor, R.G. (1996) Differential sympathetic neural control oxygenation in resting and exercising human skeletal muscle. J. Clin. Invest. 98: 584596.

Hashimoto, I., Miymura, M., and Saito, M. (1997) Initiation of increase in muscle sympathetic nerve activity delay during maximal voluntary contraction. Acta Physiol. Scand. 164: 293-297.

Herr, M.D., Imadojemu, V., Kunselman, A.L., and Sinoway, L.I. (1999) Characteristics of the muscle mechanoreflex during quadriceps contractions in humans. J. Appl. Physiol. 86: 767-772.

Johansson, J.E. (1895) Ueber die Einwirkung der Muskelthatigkeit auf die Athmung und die Hertzhiitigkeit. Skand. Arch. Physiol. 5: 20-66.

Joyner, M.J. (1991) Does the pressor response to ischemic exercise improve blood flow to contracting muscles in humans? J. Appl. Physiol. 71: 14961501.

Joyner, M.J., Nauss, L.A., Warner, M.A., and Warner, D.O. (1992) Sympathetic modulation of blood flow and $\mathrm{O} 2$ uptake in rhythmically contracting human forearm muscle. Am. J. Physiol. 263 (Heart Circ. Physiol. 32): H1078-H1083.

Mark, A.L., Victor, R.G., Nerhed, C., and Wallin, B.G. (1985) Microneurographic studies of the mechanisms of sympathetic nerve responses to static exercise. Circ. Res. 57: 461-469.

Mitchell, J.H. (1990) Neural control of the circulation during exercise. Med. Sci. Sports Exer. 22: 141154.

Pawelczyk, J.A., Hanel, B., Pawelczyk, R.A., Warberg, J., and Secher, N.H. (1992) Leg vasoconstriction during dynamic exercise with reduced cardiac 
output. J. Appl. Physiol. 73: 1838-1846.

Ray C.A. (1993a) Muscle sympathetic nerve responses to dynamic one-legged exercise: Effect of body posture. Am. J. Physiol. 264: H1-H7.

Ray. C.A. (1993b) Muscle sympathetic nerve responses to prolonged one-legged exercise. J. Appl. Physiol. 74: 1719-1722.

Ray, C.A. and Mark, A.L. (1993) Augmentation of muscle sympathetic nerve activity during fatiguing isometric leg exercise. J. Appl. Physiol. 75: 228 -232 .

Rowell, L.B., O'Leary, D.S., and Kellogg, D.L. Jr. (1996) Integration of cardiovascular Control Systems in Dynamic Exercise. In: L.B. Rowell and JT Shephered (eds) Handbook of Physiology, Section 12. Exercise Regulation and Integration of Multiple Systems. The American Physiological Society. Oxford University Press: New York, pp. 770-838.

Saito, M. (1995) Differences in muscle sympathetic nerve response to isometric exercise in different muscle groups. Eur. J. Appl. Physiol. 70: 26-35.

斉藤 満（1997）運動と交感神経活動. 宮下充正, 加賀谷淳子編 からだの「仕組み」のサイエンス. 杏林書院：東京, pp. 156-164.

斉藤 満 (2001) 運動時の末梢循環研究法. 加賀谷 淳子・中村好男編 運動と循環. ナップ：東京, pp. 8-26.

Saito, M., Abe, H., Iwase, S., Koga, K., and Mano, T. (1991) Muscle sympathetic nerve responsiveness to static contraction is not altered under hypoxia. Jpn. J. Physiol. 41: 775-783.

Saito, M., Abe, H., Iwase, S., and Mano, T. (1989) Responses of muscle sympathetic nerve activity in humans to sustained and rhythmic muscle contraction. Environ. Med. 33: 33-41.

Saito, M., Kanao, Y., Tanaka, H., and Sakai, T. (1999) Muscle sympathetic nerve responses during progressive cycling exercise. Adv. Exerc Sports Phys- iol. 5: 19-25.

Saito, M. and Mano, T. (1991) Exercise mode affect muscle sympathetic nerve responsiveness. Jpn. J. Physiol. 41: 143-151.

Saito. M., Mano, T., and Iwase, S. (1989) Sympathetic nerve activity related to local fatigue sensation during static contraction. J. Appl. Physiol. 67: 980984.

Saito, M., Sone. R., Ikeda, M., and Mano, T. (1997) Sympathetic outflow to the skeletal muscle in humans increases during prolonged light exercise. J. Appl. Physiol. 82: 1237-1243.

Saito, M., Tsukanaka, A., Yanagihara, D., and Mano, T. (1993) Muscle sympathetic nerve responses to graded leg cycling. J. Appl. Physiol. 75: 663-667.

Savard, G.K., Strange, S., Kiens, B., Richter, E.A., Christensen, N.J., and Saltin, B. (1989) Noradrenaline spillover from skeletal muscle during exercise in humans: Role of muscle mass. Am. J. Physiol. 257 (Heart Circ. Physiol. 26): H1812-H1818.

Seals, D.R., Chase, P.B., and Taylor, J.A. (1988) Autonomic mediation of the pressor responses to isometric exercise in humans. J. Appl. Physiol. 64: 2190-2196.

Victor, R.G., Bertocci. L.A., Pryor, S.L., and Nunnally, R.L. (1988) Sympatheitc nerve discharge is coupled to muscle cell pH during exercise in humans. J. Clin. Invest. 82: 1301-1305.

Victor, R.G., Seals, D.R., and Mark, A.L. (1987) Differential control of heart rate and sympathetic nerve activity during dynamic exercise. J. Clin. Invest. 79: 508-516.

Victor, R.G., Secher, N.H., Lyson, T., and Mitchell, J.H. (1995) Central command increases muscle sympthetic nerve activity during intense intermittent isometric contractions. Circ. Res. 76: 127-131.

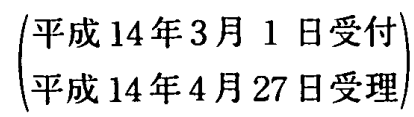

